\title{
The relationships between the average semester growth rates of lexical sophistication in L2 English writing at secondary school: A learner corpus analysis
}

\begin{abstract}
In line with Complex Dynamic Systems Theory (CDST), the aim of the paper is to examine dynamics and causality among the growth rates of lexical sophistication in L2 writing development. The study was based on The Written English Developmental Corpus of Polish Learners (WEDCPL) which consists of over 1,900 essays composed during 21 repeated measurements by 100 learners over three years (2014-2017) at secondary school. Lexical sophistication, operationalised as different frequency levels, was analysed with the Lextutor software (Cobb 2014). The results indicated that the learners relied on the first frequency level. The monthly growth rates (MGRs) of the frequency levels were variable but no significant peaks were registered. The relationships between the average semester growth rates (ASGRs) revealed competition between the first and higher frequency levels, and some support between the higher levels. Thus, developing learners' lexis beyond the first level counteracts the production of lexically unsophisticated texts and supports the use of more advanced words.
\end{abstract}

KeYwords: Complex Dynamic Systems Theory (CDST), lexical sophistication, the average semester growth rate (ASGR), L2 English writing, learner corpus.

\section{INTRODUCTION}

According to Complex Dynamic Systems Theory (CDST), language development is an emergent, non-linear, and variable process in which internally complex language subsystems progress simultaneously at different rates (LarsenFreeman \& Cameron 2008; Verspoor, deBot \& Lowie 2011; de Bot 2017). In line with the CDST principles, complexity, accuracy, and fluency, which form the so called CAF triad, are construed as "a dynamic and inter-related set of constantly changing subsystems" (Housen, Kuiken \& Vedder 2012: 9). In contrast to many CAF studies which focus on "the synchronic manifestation of CAF in task performance", CDST focuses on "their diachronic development in the course of L2 acquisition" (Housen et al. 2012: 5) adopting a more organic approach to investigating CAF (Norris \& Ortega 2009). In this sense, complexity, accuracy, 
and fluency are not only measures of L2 performance and proficiency but also indexes of L2 development. Investigating the diachronic development of CAF also allows for the analysis of the rate at which various language subsystems develop. In mainstream SLA, studies on the rate of development conducted in the 1980s reported differences between age groups with respect to selected language features on the basis of initial and final language tests (Ellis 2007). In the CDST framework, the rate of language development is construed as a dynamic construct, whose fluctuations should be studied over a longer period of time on the basis of repeated observations conducted with respect to the whole language subsystems (Larsen-Freeman 2006). It may be assumed that emergence, non-linearity, and variability observed in the learning trajectories of different language subsystems will be reflected in the trajectories of the growth rates of these subsystems over a longer period of time.

CAF studies conducted within the CDST framework focus on the development of different language subsystems (de Bot, Lowie \& Verspoor 2007; Caspi 2010; Spoleman \& Verspoor 2010; Baba \& Nita 2014; Baba 2020), inter- and intra-individual variability (Larsen-Freeman 2006; Verspoor, Lowie \& van Dijk 2008; Rokoszewska 2019a, 2019b, 2020a) as well as the competition and coordination among variables (van Geert \& Verspoor 2015; Hou, Loerts \& Verspoor 2020; Rokoszewska 2020b, 2021). So far hardly any quantitative studies on the growth rates of various language subsystems have been conducted within the CDST framework. The present paper focuses on one of the subsystems, namely lexical complexity, which is defined as the size and depth of lexical repertoire in the target language. It consists of such components as density, sophistication, diversion, and compositionality (Bulté \& Housen 2012). More precisely, it focuses on one of these components, namely lexical sophistication, and analyses the dynamics of the growth rates of different frequency levels as well as the causal relationships between them on the basis of The Written English Developmental Corpus of Polish Learners (WEDCPL) (cf. 3.4).

\section{LEXICAL SOPHISTICATION IN CDST}

Lexical sophistication refers to the depth of lexis in terms of rare, academic, or advanced words (Read 2000). At the observational level, it is quantified on the basis of various frequency-based type / token ratios. It is typically computed as the ratio of sophisticated lexical words to all lexical words in a text (Linnarud 1986; Hyltenstam 1988), with sophisticated words being defined as those which go beyond the first 2,000 most frequently used words (Wolfe-Quintero, Ingaki \& Kim 1998) as in the case of Lexical Complexity Analyser (Ai \& Lu 2010). An alternative way of examining lexical sophistication is to create the Lexical Fre- 
quency Profile (LFP) (Laufer \& Nation 1995) which shows the percentage of words from different frequency lists generated from language corpora, such as the British National Corpus (BNC), whose total size is ca. 100000 words, and the Corpus of Contemporary American English (COCA) (Davis 2012), whose size amounts to ca. 1.1 billion words. Using the software called Lextutor (Cobb 2014) various lexical profiles may be created. Profiles which specify either 20 frequency levels on the basis of the lists generated from the BNC (Nation 2004) or 25 levels on the basis of the integrated BNC and COCA lists (Nation 2012), with each level consisting of ca. 1,000 word families or lemmas, are suitable to examine language produced by native speakers or proficient L2 learners.

In the case of less proficient L2 learners, it is useful to plot lexical profiles on the basis of fewer frequency levels. The first possibility is to examine lexical sophistication in terms of four levels. In the original version, the LFP was based on the General Service List (GSL) (West 1953) and the Academic Word List (AWL), also called the University Word List (UWL) (Xue \& Nation 1984; Coxhead 2000), generated from the BNC. It indicated the proportion of words covered by the list of the first 1,000 most frequent words (GSL-1k), the list of the second 1,000 most frequent words (GSL-2k), the university word list (AWL), and none of these lists (Off-list) (Laufer \& Nation 1995). In the face of criticism of the two lists (Eldridge 2008), alternative versions of this profile were created. At present, such a profile may be based on the BNC-COCA Core- 4 lists which come from the Common Core List (CCL) (Gardner 2013), created on the basis of the first 4,000 word families in the BNC and the first 4,000 lemmas in the COCA. Alternatively, such a profile may be based on the New General Service List (NGSL) and the New Academic Word List (NAWL) generated from the Cambridge English Corpus (CEC) (Browne, Culligan \& Phillips 2013). What is more, the New Academic Word List (NAWL) may be replaced by the TSL or TOEIC service list or the Business Service List (BSL) (Browne \& Culligan 2016).

The second possibility is to analyse learners' lexical sophistication only in terms of two levels. Such a profile may be created in terms of two Common European Framework for Languages (CEFR) levels, namely level one based on the Waystage wordlist (van Ek \& Trim 1998a) and level two based on the Threshold wordlist (van Ek \& Trim 1998b). Alternatively, the Lambda value may be calculated by means of lognostics tools (Meara \& Miralpeix 2016). This value is based on the analysis of texts divided into 10-word-long segments and scrutinised in terms of words from the first 1,000 frequent words and words beyond this level (Meara \& Bell 2001).

The third possibility is to create a profile based on shorter frequency lists which do not consist of 1,000 but 100 word families. This can be done by the use of BNC-COCA Core 1-25 'c-series', i.e. lists which provide 25 levels, each 
consisting of 100 heads. This kind of profile is useful to measure progress in terms of lexical frequency at the early stages of language learning for which $1 \mathrm{k}$ level is too general to capture minor changes. It is important to add that lexical sophistication may also be examined by other computer programmes, such as CLAN (McWhinney 2000), Range (Nation \& Heatley 2002), AntWord Profiler (Anthony 2014), or Text Inspector (2018). However, it is crucial to check what lexical frequency lists are used in a given programme.

Studies on lexical complexity conducted within the CDST framework typically analyse the co-development of lexical density, sophistication, and variation over a longer period of time at the university level. Some studies reported an increase in the development of sophistication and variation at the cost of density (Duran, Malvern, Richards \& Chipere 2004; Storch \& Tapper 2009; Zheng 2016), whereas other studies revealed no statistically significant gains in the development of these measures (Bulté \& Housen 2014; Knoch, Rouhshad \& Storch 2015). The present paper focuses on the co-development of different frequency levels within lexical sophistication in L2 English writing at secondary school. More precisely, it describes the dynamics and causality of the growth rates of these frequency levels providing dense quantitative data.

\section{METHOD}

\subsection{Research aims}

The general aim of the present study was to examine the average semester growth rates (ASGR) of lexical sophistication in the development of L2 English writing at secondary school. More specifically, the aim of the study was to examine the development of lexical sophistication in terms of different frequency levels, the dynamics of the growth rates of different frequency levels on the monthly basis, i.e. the monthly growth rates (MGR), as well as the average semester growth rates of these levels (ASGR) and the relationships between them. With respect to the aims of the study, the following research questions were formulated:

1. What results do learners obtain on lexical sophistication in terms of different frequency levels in the development of L2 English writing at secondary school?

2. What is the monthly growth rate (MGR) of lexical sophistication in terms of different frequency levels in the development of L2 English writing at secondary school?

3. What are the average semester growth rates (ASGR) of lexical sophistication in terms of different frequency levels in the development of L2 English writing at secondary school? 
4. What relationships take place between the average semester growth rates (ASGR) of lexical sophistication in terms of different frequency levels in the development of L2 English writing at secondary school?

\subsection{Research method}

The present study was a corpus-based quantitative type of study. It provided both cross-sectional and longitudinal data in a time developmental series. The study combined focused description, used to analyse causality between selected variables, with some CDST procedures, implemented to analyse the dynamics of their development. It was based on The Written English Developmental Corpus of Polish Learners (WEDCPL) which included over 1900 written texts.

As for the research variables, lexical sophistication was operationalised as the proportion of words from different frequency levels in a written text (cf. 3.5). The monthly growth rate (MGR) was operationalised as the change of a given variable in the period of one month in relation to the level of this variable in the previous period, whereas the average semester growth rate (ASGR) as the average difference between the tests conducted in a given semester (cf. 3.5). Taking into consideration a relatively slow process of language development, the learners' progress was calculated in terms of semesters (cf. 4.3).

\subsection{Research participants}

The research sample was based on existing language groups at secondary school whose language development was traced for three school years, i.e. six semesters. A random sampling technique was not used as it was assumed that the sample should fulfil such criteria as the same language level, coursebook, and number of lessons per week within an extended English programme. The sample included 100 Polish secondary school learners, i.e. 45 girls and 55 boys, who were at the age of 16 in the first grade. They were taught by five different teachers in seven language groups. Prior to the study, they had been learning English for about nine years. At secondary school, they had from 4 to 6 lessons per week depending on the grade. In the first grade, they were at the intermediate level (B1), whereas in the second and third grades - at the upper-intermediate level (B2). Their grade point average (GPA) of all school subjects and English per three grades was 4.0 on the 1-6 grading scale. At the final exam, the learners obtained $91.8 \%$ and $72.1 \%$ for the written part at the basic (B1) and extended (B2) levels, respectively, and $72.1 \%$ for the oral part. 


\subsection{Data collection}

The Written English Developmental Corpus of Polish Learners (WEDCPL) was created on the basis of 21 data waves (Hiver \& Al-Hoorie 2020) during which the samples of L2 English writing, in the form of timed essays, were collected from 100 learners over the period of three years. The corpus includes 1924 per 2100 texts, with the return rate equal to $91.6 \%$. The size of the corpus analysed on the basis of the written samples was 393202 words, with the average length of the samples being 204 words. The procedure of building the corpus consisted of the following stages: writing compositions without reference materials during English lessons every month, storing the scans of the essays in computer files, marking the essays and storing them in regular files, preparing electronic transcripts by means of the speech recognition program called Dragon Naturally Speaking (Nuance ${ }^{\circledR} 2014$ ), verifying the transcripts and preserving the learners' errors, and preparing appropriate text samples. The procedure of lexical sophistication analysis involved two stages, namely pre-processing the written samples so that the words in these samples would be recognized by the computer programme (Rokoszewska 2020b), and analysing the samples by means of the programme called Lextutor (Cobb 2014).

Table 1. Research design in a time series

\begin{tabular}{|c|c|c|c|c|c|c|c|c|c|c|}
\hline \multicolumn{11}{|c|}{ RESEARCH DESIGN IN TIME SERIES } \\
\hline \multirow{2}{*}{ DATA } & \multicolumn{5}{|c|}{ SEMESTER 1} & \multicolumn{5}{|c|}{ SEMESTER 2} \\
\hline & Sept & Oct. & Nov. & Dec. & Jan. & Feb. & March & April & May & June \\
\hline $\begin{array}{c}\text { GRADE } \\
1 \\
\end{array}$ & Org. & $\begin{array}{c}\text { Test } 1 \\
\text { Fashion }\end{array}$ & $\begin{array}{c}\text { Test } 2 \\
\text { Internet }\end{array}$ & $\begin{array}{l}\text { Test } 3 \\
\text { Music }\end{array}$ & $\begin{array}{c}\text { Test } 4 \\
\text { Education } \\
\end{array}$ & $\begin{array}{c}\text { Winter } \\
\text { break }\end{array}$ & $\begin{array}{c}\text { Test } 5 \\
\text { Ecology }\end{array}$ & $\begin{array}{c}\text { Test } 6 \\
\text { Pets } \\
\end{array}$ & $\begin{array}{l}\text { Test } 7 \\
\text { Work }\end{array}$ & $\begin{array}{c}\text { Test } 8 \\
\text { Holidays }\end{array}$ \\
\hline $\begin{array}{c}\text { GRADE } \\
2\end{array}$ & Org. & $\begin{array}{c}\text { Test } 9 \\
\text { Books \& } \\
\text { films }\end{array}$ & $\begin{array}{l}\text { Test } 10 \\
\text { Shopping }\end{array}$ & $\begin{array}{c}\text { Test } 11 \\
\text { Friendship }\end{array}$ & $\begin{array}{c}\text { Test } 12 \\
\text { Christmas }\end{array}$ & $\begin{array}{c}\text { Winter } \\
\text { break }\end{array}$ & $\begin{array}{l}\text { Test } 13 \\
\text { Family }\end{array}$ & $\begin{array}{l}\text { Test } 14 \\
\text { Health }\end{array}$ & $\begin{array}{l}\text { Test } 15 \\
\text { Fame }\end{array}$ & $\begin{array}{l}\text { Test } 16 \\
\text { Home \& } \\
\text { living }\end{array}$ \\
\hline $\begin{array}{c}\text { GRADE } \\
3\end{array}$ & Org. & $\begin{array}{l}\text { Test } 17 \\
\text { Love }\end{array}$ & $\begin{array}{c}\text { Test } 18 \\
\text { TV }\end{array}$ & $\begin{array}{l}\text { Test } 19 \\
\text { Crime }\end{array}$ & $\begin{array}{l}\text { Winter } \\
\text { break }\end{array}$ & $\begin{array}{c}\text { Test } 20 \\
\text { Terror- } \\
\text { ism }\end{array}$ & $\begin{array}{l}\text { Test } 21 \\
\text { Toler- } \\
\text { ance }\end{array}$ & $\begin{array}{c}\text { End of } \\
\text { school- } \\
\text { year }\end{array}$ & $\begin{array}{l}\text { Mat- } \\
\text { ura } \\
\text { exam }\end{array}$ & - \\
\hline
\end{tabular}

Source: Rokoszewska (2019a, 2019b, 2020a, 2020b).

\subsection{Data analysis}

Data analysis involved a number of procedures. Lexical sophistication was calculated in the form of the Lexical Frequency Profile (LFP), based on the BNC-COCA Core-4 frequency lists by means of the Lextutor software (Cobb 2014). The profile consisted of four frequency levels, namely the first 1,000 most frequent words ( $1 \mathrm{k}$ words), the second 1,000 most frequent words ( $2 \mathrm{k}$ words), 
the third 1,000 most frequent words (3k words), and the off-list words. The monthly growth rate (MGR) was calculated on the basis of standardised scores, i.e. $z$ scores, according to the formula below, in which $R$ stands for the growth rate and $\bar{X}$ - for the mean on a given test, and the first measurement is set with the 0 value as the baseline (Larsen-Freeman, 2006) ${ }^{1}$.

$$
\left.M G R=\left(\overline{\mathrm{X}}_{\mathrm{i}+1}-\overline{\mathrm{X}}_{\mathrm{i}}\right) / \overline{\mathrm{X}}_{\mathrm{i}}\right)
$$

The average semester growth rate (ASGR) was computed according to the formula below, in which $n$ stands for the number of scores, $\Pi$ - for the product, and $x_{i}-$ for the $i$-th score.

$$
A M G R=\left(\sqrt[n-1]{\prod_{i=2}^{n} \frac{x_{i}}{x_{i-1}}}-1\right) \cdot 100 \%
$$

What is more, the probability test was conducted to calculate the probability with which other learners would obtain similar results on the average semester growth rates of lexical sophistication in a similar context in the future.

In addition, data analysis involved some CDST procedures, such as delineating general trends in a time series by means of the 2 nd degree polynomials, standardising the data to analyse the dynamics of the growth rate in time, and using a Monte Carlo Analysis (5,000 iterations, $a=0.05)$ to check the significance of peaks in the trajectories of the growth rates (Larsen-Freeman 2006; Verspoor, Lowie, van Geert, van Dijk \& Schmid 2011). A significant peak was defined as "the distance between the minimum and maximum observation in a given data set" (van Dijk, Verspoor \& Lowie 2011: 80) as opposed to one isolated jump resulting from temporary fluctuations.

\section{RESULTS}

\subsection{The development of lexical frequency levels}

In general, the results of the study indicated that the learners, on average, used $89.8 \%(\mathrm{SD}=2.56)$ of $1 \mathrm{k}$ words, $4.3 \%$ of $2 \mathrm{k}$ words $(\mathrm{SD}=1.51), 2.0 \%$ of $3 \mathrm{k}$ words ( $\mathrm{SD}=1.28)$, and $3.2 \%$ of the off-list words $(\mathrm{SD}=1.21)$ in L2 English writing at secondary school (cf. Table 2, Figures 1-4). The trend in the development of $1 \mathrm{k}$ words showed some increase in the middle of the observation period, but it was generally decreasing (Figure 1). The trend in the development of $2 \mathrm{k}$ words

\footnotetext{
${ }^{1}$ In order to express the rate in percentages, the final result may be multiplied by $100 \%$. However, for the clarity of the graphs, the dynamics of the monthly growth rates was calculated in points.
} 
illustrated some increase over time (Figure 2). The trend in the development of $3 \mathrm{k}$ words was a mirror reflection of the trend in the development of $1 \mathrm{k}$ words it revealed some decrease in the middle of the observation period, but it was generally increasing (cf. Figure 3). The trend in the development of the off-list words was the so-called damped trend (Hiver \& Al-Hoorie 2020) - it revealed a systematic decrease over the whole learning period (cf. Figure 4).

Table 2. The development of lexical frequency levels

\begin{tabular}{|l|c|c|c|c|}
\hline \multicolumn{5}{|c|}{ THE DEVELOPMENT OF LEXICAL FREQUENCY LEVELS } \\
\hline \multicolumn{1}{|c|}{ DATA } & 1K WORDS & 2K WORDS & 3K WORDS & OFF-LIST WORDS \\
\hline X & 89.8 & 4.3 & 2.0 & 3.2 \\
\hline SD & 2.56 & 1.51 & 1.28 & 1.21 \\
\hline Min & 85.1 & 2.6 & 0.9 & 1.7 \\
\hline Max & 93.3 & 8.2 & 6.1 & 6.7 \\
\hline
\end{tabular}

THE DEVELOPMENT OF LEXICAL SOPHISTICATION - $1 \mathrm{~K}$ WORDS

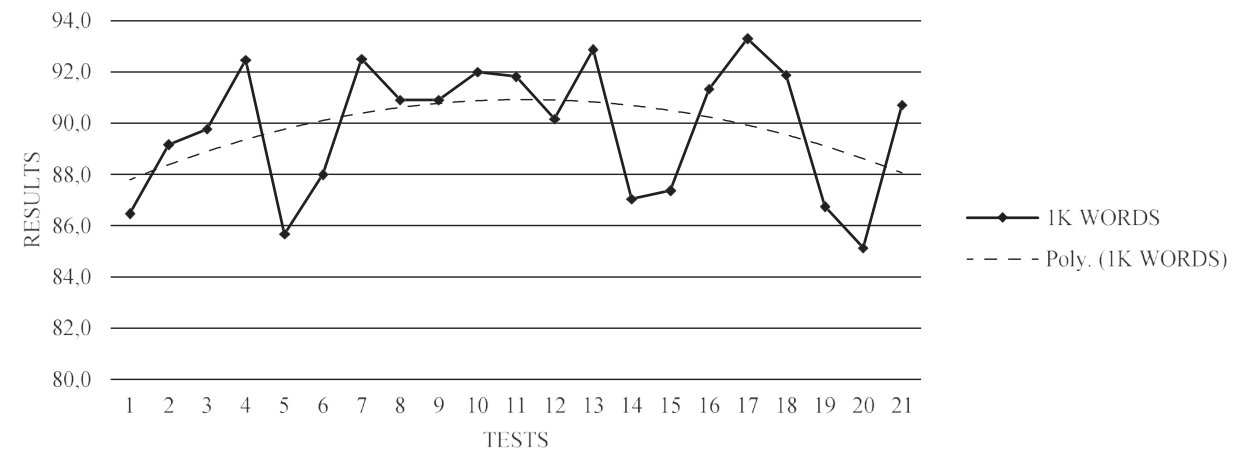

Figure 1. The development of lexical sophistication - 1k words (raw data)

THE DEVELOPMENT OF LEXICAL SOPHISTICATION - 2 K WORDS

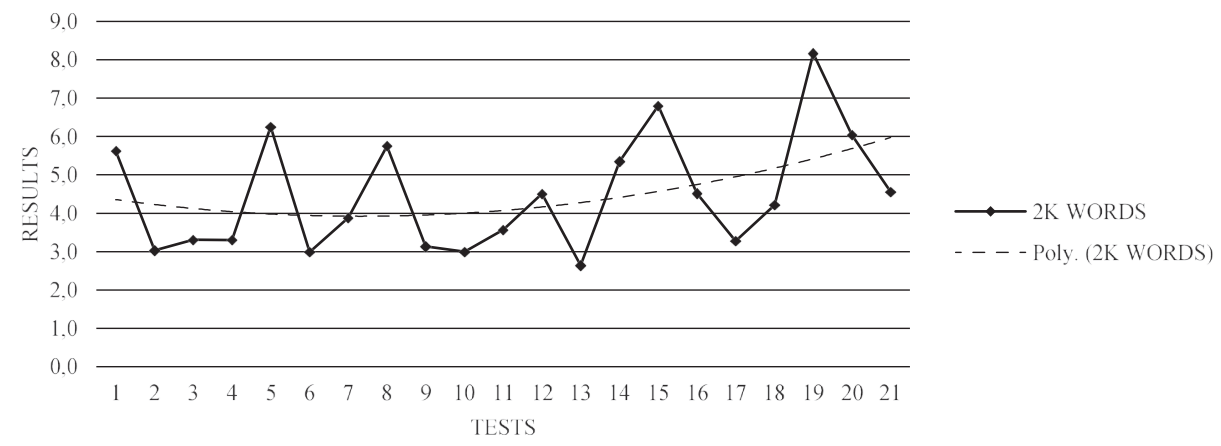

Figure 2. The development of lexical sophistication - 2k words (raw data) 
THE DEVELOPMENT OF LEXICAL SOPHISTICATION - 3 K WORDS

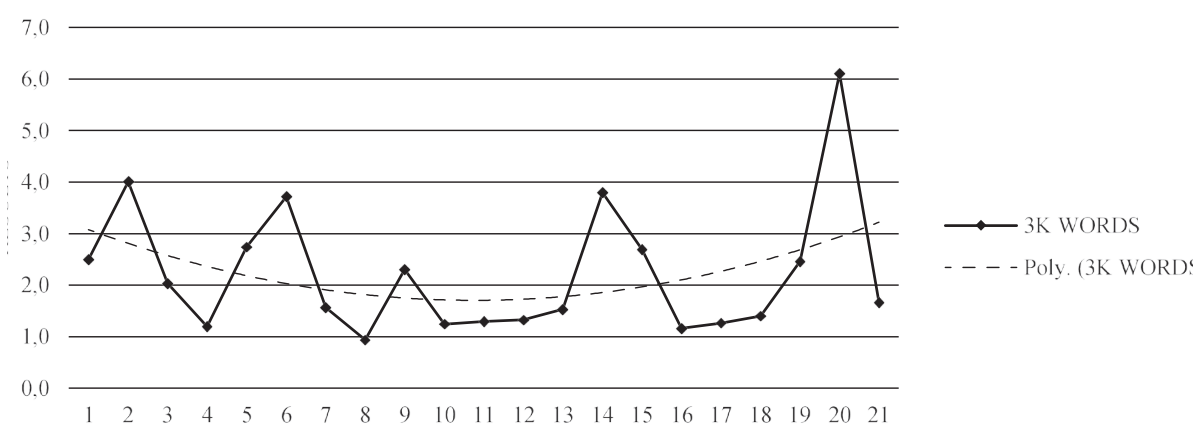

Figure 3. The development of lexical sophistication - 3k words (raw data)

THE DEVELOPMENT OF LEXICAL SOPHISTICATION - OFF-LIST WORDS

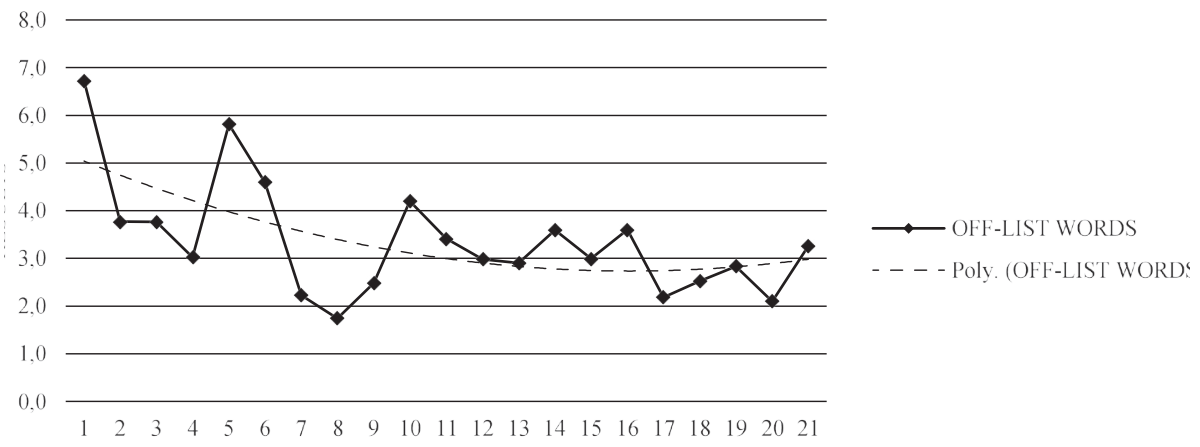

Figure 4. The development of lexical sophistication - the off-list words (raw data)

The statistical analysis, based on the U-Mann Whitney Test, indicated that the proportion of $1 \mathrm{k}$ words was the highest, the proportion of $2 \mathrm{k}$ words was higher than the proportion of $3 \mathrm{k}$ words and the off-list words, but the proportion of $3 \mathrm{k}$ words was lower than the proportion of the off-list words (cf. Table 3).

Table 3. The differences between vocabulary use from different frequency levels

\begin{tabular}{|c|c|c|c|c|}
\hline \multicolumn{5}{|c|}{$\begin{array}{l}\text { THE DIFFERENCES BETWEEN THE AVERAGE RESULTS ON DIFFERENT FREQUENCY } \\
\text { LEVELS }\end{array}$} \\
\hline DATA & 1K WORDS & 2K WORDS & 3K WORDS & $\begin{array}{l}\text { OFF-LIST } \\
\text { WORDS }\end{array}$ \\
\hline 1K WORDS & - & $0.00^{*}$ & $0.00^{*}$ & $0.00^{*}$ \\
\hline 2K WORDS & - & - & $0.00^{*}$ & $0.01^{*}$ \\
\hline 3K WORDS & - & - & - & $0.00^{*}$ \\
\hline OFF-LIST WORDS & - & - & - & - \\
\hline
\end{tabular}

Note: An asterisk indicates statistically significant differences - U-Mann Whitney test $(a=0.05, N=100)$. 


\subsection{The monthly growth rates of lexical frequency levels}

With respect to the monthly growth rates (MGR) of lexical frequency levels (cf. Table 4, Figure 5), the results of the present study indicated that the rate of the first frequency level increased by 7.9 points on test 13 but decreased by 51.5 points on test 4 with respect to the preceding test. The rate of the second frequency level increased by 1.7 points on test 15 , but it decreased by 54.7 points on test 13 and by 29.4 points on test 17 . Furthermore, the monthly growth rate of the third frequency level went up by 5.9 points on test 2 , by 4.2 points on test 4 , and by 15.9 points on test 20, but it went down by 15.4 points on test 10. Finally, the rate of the fourth frequency level went up by 1.4 points on test 20 , but it went down by 8.1 points on test 5 , by 9.0 points on test 12 , and by 6.1 points on test 17 .

Table 4. The monthly growth rates of lexical frequency

\begin{tabular}{|c|c|c|c|c|c|c|c|c|c|c|c|}
\hline \multicolumn{12}{|c|}{ THE MONTHLY GROWTH RATES OF LEXICAL FREQUENCY } \\
\hline \multicolumn{12}{|c|}{ 1K WORDS } \\
\hline TESTS & $\mathrm{T} 1$ & $\mathrm{~T} 2$ & T3 & $\mathrm{T} 4$ & T5 & T6 & $\mathrm{T} 7$ & $\mathrm{~T} 8$ & T9 & $\mathrm{T} 10$ & $\mathrm{~T} 11$ \\
\hline Rate & 0.0 & -0.8 & -0.9 & -51.5 & -2.6 & -0.6 & -2.5 & -0.6 & 0.0 & 1.0 & -0.1 \\
\hline TESTS & $\mathrm{T} 12$ & $\mathrm{~T} 13$ & $\mathrm{~T} 14$ & $\mathrm{~T} 15$ & $\mathrm{~T} 16$ & $\mathrm{~T} 17$ & $\mathrm{~T} 18$ & $\mathrm{~T} 19$ & $\mathrm{~T} 20$ & $\mathrm{~T} 21$ & \multirow{2}{*}{-} \\
\hline Rate & -0.8 & 7.9 & -1.9 & -0.1 & -1.6 & 1.3 & -0.4 & -2.5 & 0.5 & -1.2 & \\
\hline \multicolumn{12}{|c|}{ 2K WORDS } \\
\hline TESTS & $\mathrm{T} 1$ & $\mathrm{~T} 2$ & T3 & $\mathrm{T} 4$ & T5 & T6 & $\mathrm{T} 7$ & $\mathrm{~T} 8$ & T9 & $\mathrm{T} 10$ & $\mathrm{~T} 11$ \\
\hline Rate & 0.0 & -2.2 & -0.2 & 0.0 & -2.5 & -1.8 & -0.6 & -3.2 & -2.0 & 0.1 & -0.4 \\
\hline TESTS & $\mathrm{T} 12$ & T13 & $\mathrm{T} 14$ & T15 & $\mathrm{T} 16$ & $\mathrm{~T} 17$ & $\mathrm{~T} 18$ & T19 & $\mathrm{T} 20$ & $\mathrm{~T} 21$ & \multirow{2}{*}{-} \\
\hline Rate & -1.0 & -54.7 & -1.5 & 1.7 & -1.0 & -29.4 & -0.8 & -15.4 & -0.6 & -0.9 & \\
\hline \multicolumn{12}{|c|}{ 3K WORDS } \\
\hline TESTS & $\mathrm{T} 1$ & $\mathrm{~T} 2$ & T3 & $\mathrm{T} 4$ & T5 & T6 & $\mathrm{T} 7$ & $\mathrm{~T} 8$ & T9 & $\mathrm{T} 10$ & $\mathrm{~T} 11$ \\
\hline Rate & 0.0 & 5.9 & -1.1 & 4.2 & -1.5 & 1.9 & -1.5 & 0.9 & -1.1 & -15.4 & -0.1 \\
\hline TESTS & $\mathrm{T} 12$ & $\mathrm{~T} 13$ & $\mathrm{~T} 14$ & $\mathrm{~T} 15$ & $\mathrm{~T} 16$ & T17 & $\mathrm{T} 18$ & T19 & $\mathrm{T} 20$ & $\mathrm{~T} 21$ & \multirow{2}{*}{-} \\
\hline Rate & 0.0 & -0.2 & -3.2 & -0.7 & -3.4 & -0.1 & -0.1 & -1.3 & 15.9 & -1.1 & \\
\hline \multicolumn{12}{|c|}{ OFF-LIST WORDS } \\
\hline TESTS & $\mathrm{T} 1$ & $\mathrm{~T} 2$ & $\mathrm{~T} 3$ & $\mathrm{~T} 4$ & T5 & T6 & $\mathrm{T} 7$ & $\mathrm{~T} 8$ & T9 & $\mathrm{T} 10$ & $\mathrm{~T} 11$ \\
\hline Rate & 0.0 & -0.9 & 0.0 & -1.9 & -8.1 & -0.5 & -1.9 & 0.4 & -0.5 & -1.9 & -0.9 \\
\hline TESTS & $\mathrm{T} 12$ & $\mathrm{~T} 13$ & $\mathrm{~T} 14$ & T15 & $\mathrm{T} 16$ & T17 & $\mathrm{T} 18$ & T19 & $\mathrm{T} 20$ & $\mathrm{~T} 21$ & - \\
\hline Rate & -9.0 & 0.2 & -1.5 & -2.7 & -1.6 & -6.1 & -0.3 & -0.4 & 1.4 & -0.9 & \\
\hline
\end{tabular}




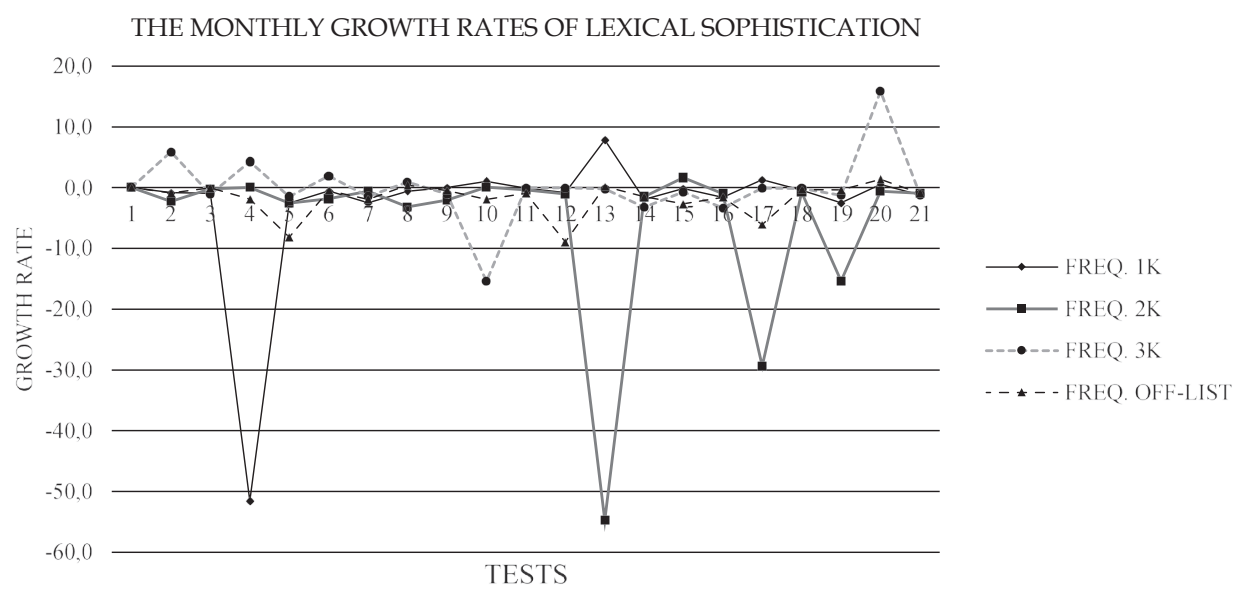

Figure 5. The monthly growth rates of lexical sophistication

As far as the significance of peaks in the trajectories of the monthly growth rates of different frequency levels is concerned, a Monte Carlo analysis, conducted with 5,000 iterations at the level of significance $a$ equal 0.05 , revealed insignificant peaks in the rates of all frequency levels, i.e. $1 \mathrm{k}$ words $(p=0.23), 2 \mathrm{k}$ words $(p=0.28), 3 \mathrm{k}$ words $(p=0.62)$, and the off-list words $(p=0.54)$ (cf. Table 5).

Table 5. The significance of peaks in the monthly growth rates of lexical sophistication

\begin{tabular}{|c|c|c|c|}
\hline \multicolumn{4}{|c|}{ THE SIGNIFICANCE OF PEAKS IN THE MONTHLY GROWTH RATES } \\
OF LEXICAL SOPHISTICATION \\
\hline 1K WORDS & 2K WORDS & 3K WORDS & OFF-LIST WORDS \\
\hline 0.23 & 0.28 & 0.62 & 0.54 \\
\hline
\end{tabular}

Note: An asterisk indicates statistically significant correlations - a Monte Carlo analysis $(a=0.05, N=21)$.

\subsection{The average semester growth rates of lexical sophistication}

In order to provide a more general picture of the tempo at which lexical sophistication developed, the average semester growth rates (ASGR) of the selected frequency levels were calculated. It was established that the average semester growth rate of $1 \mathrm{k}$ words was equal to $0.06 \%(\mathrm{SD}=0.70)$, whereas this kind of rate of $2 \mathrm{k}$ words equalled $8.12 \%$ (SD = 8.22). Furthermore, the average semester growth rate of $3 \mathrm{k}$ words was $0.73 \%(\mathrm{SD}=10.02)$ while such rate of the off-list words was $-11.31 \%(\mathrm{SD}=8.31)$ (Table 6). 
Table 6. The average semester growth rates in lexical sophistication

\begin{tabular}{|l|c|c|c|c|}
\hline \multicolumn{4}{|c|}{ THE AVERAGE SEMESTER GROWTH RATES OF LEXICAL SOPHISTICATION } \\
\hline DATA & 1K WORDS & 2K WORDS & 3K WORDS & $\begin{array}{c}\text { OFF-LIST } \\
\text { WORDS }\end{array}$ \\
\hline ASGR & 0.06 & 8.12 & 0.73 & -11.31 \\
\hline SD & 0.70 & 8.22 & 10.02 & 8.31 \\
\hline Min & -2.22 & -9.55 & -22.38 & -34.15 \\
\hline Max & 1.72 & 35.42 & 23.04 & 20.21 \\
\hline
\end{tabular}

The statistical analysis conducted on the basis of the U-Mann Whitney test indicated that the average growth rate of $2 \mathrm{k}$ words was the highest, whereas the growth rates of $1 \mathrm{k}$ words and $3 \mathrm{k}$ words were the same, but at the same time, they were higher than the rate of the off-list words (Table 7).

Table 7. The differences between the average semester growth rates of lexical sophistication

\begin{tabular}{|l|c|c|c|c|}
\hline \multicolumn{5}{|c|}{ THE DIFFERENCES BETWEEN THE AVERAGE SEMESTER GROWTH RATES } \\
OF LEXICAL SOPHISTICATION
\end{tabular}

Note: An asterisk indicates statistically significant differences - a Monte Carlo analysis $(a=0.05, N=100)$.

In addition, the probability that in the case of other learners, the average semester growth rates of $2 \mathrm{k}$ words would be higher than the rates of all other levels, and that the rates of all levels would be higher than the rates of off-list words was quite high (cf. Table 8).

Table 8. The differences between the average semester growth rates the hypothetical probability level

\begin{tabular}{|c|c|c|c|}
\hline \multicolumn{4}{|c|}{$\begin{array}{l}\text { THE DIFFERENCES BETWEEN THE AVERAGE SEMESTER GROWTH RATES } \\
\text { OF LEXICAL SOPHISTICATION - THE HYPOTHETICAL PROBABILITY LEVEL }\end{array}$} \\
\hline \multirow{6}{*}{ ASGR } & $2 \mathrm{k}$ words & $1 \mathrm{k}$ words & $74.0 \%$ \\
\hline & $2 \mathrm{k}$ words & $3 \mathrm{k}$ words & $65.0 \%$ \\
\hline & $3 \mathrm{k}$ words & $1 \mathrm{k}$ words & $46.0 \%$ \\
\hline & $1 \mathrm{k}$ words & off-list words & $85.0 \%$ \\
\hline & $2 \mathrm{k}$ words & off-list words & $94.0 \%$ \\
\hline & $3 \mathrm{k}$ words & off-list words & $82.0 \%$ \\
\hline
\end{tabular}




\subsection{The relationships between the semester growth rates of lexical frequency levels}

The analysis of the relationships between the average semester growth rates of lexical frequency levels revealed a number of statistically significant relationships (cf. Table 9). The correlations were statistically significant if the linear correlation coefficient $r$ was equal to or greater than the critical value $\left(r^{*}\right)$ which was equal to 0.20 at the 0.05 alfa significance $(a=0.05)$. The analysis revealed that the relationships between the average semester growth rate of $1 \mathrm{k}$ words and the rates of other frequency bands was negative. More precisely, it was quite strong in the case of $1 \mathrm{k}$ and $2 \mathrm{k}$ words $\left(r=-0.72^{*}\right)$ and moderate in the case of $1 \mathrm{k}$ and $3 \mathrm{k}$ words $\left(r=-0.56^{*}\right)$ as well as in the case of $3 \mathrm{k}$ words and the off-list words $\left(r=-0.64^{*}\right)$. Furthermore, the relationship between the rates of $2 \mathrm{k}$ words and the off-list words $\left(r=0.31^{*}\right)$ as well as the relationship between the rates of $3 \mathrm{k}$ words and the off-list words $\left(r=0.22^{*}\right)$ were weak and positive. However, the relationship between the rates of $2 \mathrm{k}$ and $3 \mathrm{k}$ words was insignificant $\left(r=0.09^{*}\right)$.

Table 9. The relationships between the average semester growth rates of lexical sophistication

\begin{tabular}{|l|c|c|c|c|}
\hline \multicolumn{5}{|c|}{ THE RELATIONSHIPS BETWEEN THE AVERAGE SEMESTER GROWTH RATES } \\
(ASGR) OF LEXICAL SOPHISTICATION
\end{tabular}

Note: An asterisk indicates statistically significant correlations $(a=0.05, N=100)$.

In addition, the linear regression models revealed that the increase in the average rate of growth of $1 \mathrm{k}$ words by $1 \%$ would cause a decrease of such a rate of $2 \mathrm{k}$ words on average by $8.39 \%$. In this model, the amount of variance in the rate of $2 \mathrm{k}$ words was explained by the rate of $1 \mathrm{k}$ words in $51.2 \%$ (cf. Figure 6 ). Furthermore, the increase in the average rate of growth of $1 \mathrm{k}$ words by $1 \%$ would lead to a decrease in the rate of $3 \mathrm{k}$ words on average by $7.94 \%$, with shared variance between the variables equal to $30.81 \%$ (cf. Figure 7). Finally, such an increase in the rate of $1 \mathrm{k}$ words would result in the decreasing rate of the off-list words by $7.55 \%$, with shared variance of $40.59 \%$ (cf. Figure 8 ). 
THE CORRELATION BETWEEN THE AVERAGE SEMESTER GROWTH RATES (ASGR) OF 1K AND 2K WORDS

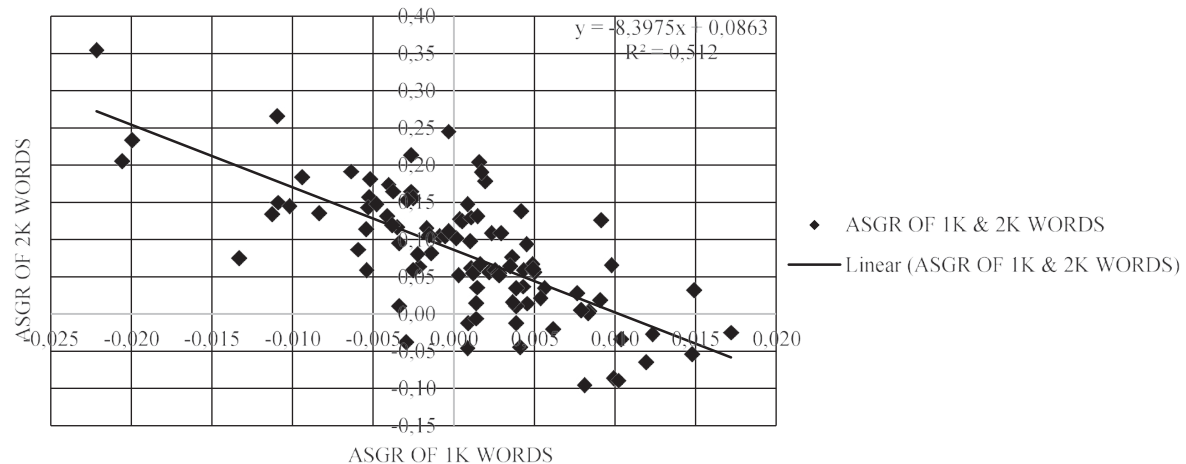

Figure 6 . The correlation between the rates of $1 \mathrm{k}$ and $2 \mathrm{k}$ words - the linear regression model THE CORRELATION BETWEEN AVERAGE SEMESTER GROWTH RATES (ASGR) OF 1K AND 3K WORDS

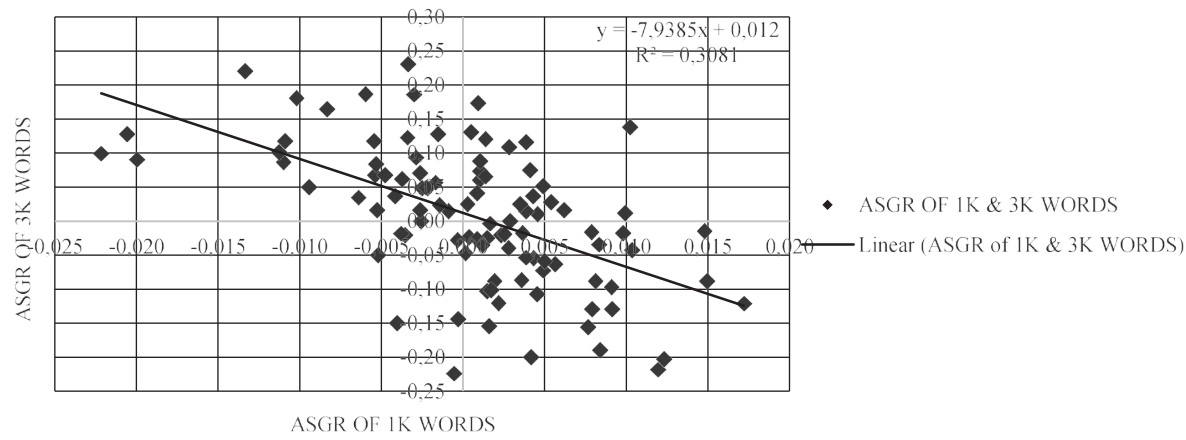

Figure 7. The correlation between the rates of $1 \mathrm{k}$ and $3 \mathrm{k}$ words - the linear regression model

THE CORRELATION BETWEEN AVERAGE SEMESTER GROWTH RATES (ASGR) OF 1K AND OFF-LIST WORDS

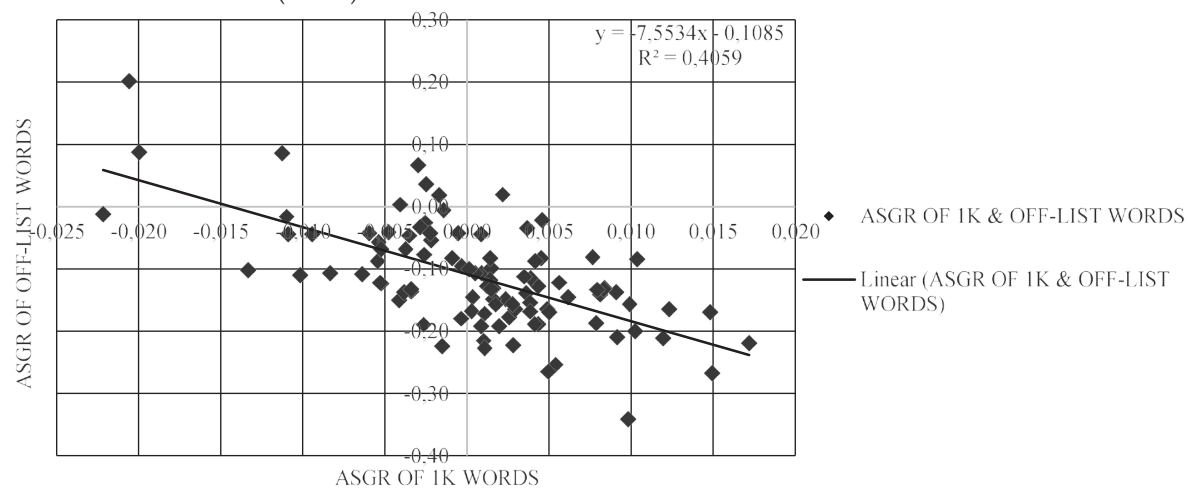

Figure 8. The correlation between the rates of $1 \mathrm{k}$ and the off-list words - the linear regression mode 


\section{DISCUSSION}

The aim of the present paper was to examine the dynamics of the growth rates of lexical sophistication in terms of different frequency levels and the relationships between them in the development of L2 English writing at the level of secondary school. With respect to the first research question, which focused on the learners' results on the development of lexical sophistication, it was found out that the learners relied mainly on the first frequency level at the cost of further frequency levels. This indicates that the learners' texts were characterised with communicative efficiency, as opposed to lexical sophistication, since the learners were able to discuss a variety of topics in writing using rather simple lexis. What is more, they automatically accessed words from the most basic level in writing in contrast to words from the further frequency levels introduced during the inter-mediate and upper-intermediate courses at school, which signals that the quality and quantity of vocabulary practice might have been insufficient to foster the use of more sophisticated lexis. More precisely, the implementation of formal practice and the use of controlled vocabulary activities to the disadvantage of more naturalistic language practice and the use of free activities might have made it difficult to narrow the gap between controlled and free vocabulary use. Nevertheless, the results showed some progress in that the general trend in the first frequency level was decreasing, whereas the trends in the second and third frequency levels were increasing.

With respect to the second research question, which refers to the dynamics of the growth rates of lexical sophistication, it was observed that the monthly growth rates of lexical sophistication were not linear, incremental, and systematic but non-linear, dynamic, and variable. They did not progress from the lowest to the highest rate but involved peaks and lows over time, which is consistent with the CDST view of language as a complex system. The rates of all frequency levels fluctuated to some extent, but it seems that the rate of the second level fluctuated the most, which might indicate some activity in this subcomponent of lexical sophistication and reflect the learners' increasing ability to use more sophisticated words. Furthermore, analysing the fluctuations in the monthly growth rates with respect to the topics of the essays, it was observed that the growth rate of $1 \mathrm{k}$ words decreased substantially on the topic about ecology (test 4) but increased to some extent on one of the most common topics, namely 'Family' (test 13). The growth rate of $2 \mathrm{k}$ words decreased on the topics connected with family (test 13), love (test 17), and crime (19), whereas the growth rate of $3 \mathrm{k}$ words decreased on the topic about shopping (test 10) but increased on the topic connected with terrorism (test 20). Thus, despite the iterative research pro- 
cedure, a variety of topics might have influenced the dynamics of the monthly growth rates. Nevertheless, it is vital to point out that the Monte Carlo analysis showed that all these fluctuations were statistically insignificant, which means that the learners taught in the formal EFL context did not achieve a significant peak in the monthly growth rates of lexical frequency levels. On the one hand, it might be caused by developing other language subsystems at the cost of lexical sophistication due to intrinsic trade-offs in their development caused by the learners' inability to allocate their linguistic and cognitive resources to all subsystems at once. On the other hand, it might be due to insufficient language practice mentioned above.

With respect to the third research question, which refers to the average semester growth rates of lexical sophistication, it was calculated that the second frequency level developed at the highest rate and that the growth rates of the first and third frequency levels, which did not differ, were higher than the rate of the off-list level. What is more, the probability that other learners would obtain similar results was relatively high. Taking into consideration the fact that the increase in the second frequency level was most substantial and the growth rate was the highest, it may be concluded that the learners at B1 and B2 level were ready to focus on the second frequency level and would hopefully continue to do so in their further language development. In general, these results provide some evidence for the CDST claim that different components of the same language subsystem may develop at different rates.

With respect to the last research question, which focused on the relationships between the average semester growth rates of the selected frequency levels, it was established that the relationship between the rate of the first frequency level had a rather strong negative influence on the rates of the second, third, and offlist frequency levels. Indeed, an increase in the growth rate of the words from the most basic level caused a decrease in the growth rates of the words from more advanced levels. In contrast, the relationship between the growth rates of the second frequency level and the off-list words as well as the relationship between the third frequency level and the off-list words were positive. However, the relationship between the rates of the second and third frequency levels was insignificant. Nevertheless, it may be concluded that there exists strong competition between the growth rate of the most basic frequency level and the rates of the higher levels, which contrasts with some support between the rates of higher levels. This means that supporting learners' development of lexis beyond the first level counteracts the production of lexically unsophisticated texts and supports the use of more advanced words. 


\section{CONCLUSIONS, LIMITATIONS, AND IMPLICATIONS}

The present study has provided some insight into the dynamics and development of lexical sophistication in L2 English writing at secondary school. The results of the study indicated significant differences between different frequency levels but insignificant fluctuations in the trajectories of the monthly growth rates of these levels. More importantly, however, the study revealed significant differences between the average semester growth rates (ASGR) of the selected frequency bands and significant relationships between them, which points to high competition between the lower and higher frequency levels and some support between the higher levels. Nevertheless, the present study is not free from some limitations. In the face of the results which showed that the learners used mostly words from the first frequency level, it would be advisable to investigate this level in more detail using frequency lists which divide it into subcategories. It is also important to point out that the learners' results on lexical sophistication might have been influenced by the topics of the essays. Although the study design was based on the reiterative procedure of timed essay writing under the same conditions, the topics differed from one measurement to another. Despite the fact that they were based on the learners' coursebooks and covered during English lessons at school, they might have presented the learners with different levels of difficulty.

Despite some limitations, the study offers important implications for English teachers. Firstly, teachers should realize that language development does not involve only accuracy and fluency but also complexity at the syntactic and lexical level. What is more, they should be aware of the fact that the development of lexical complexity, including the development of lexical sophistication, is a long and complex process in which vocabulary introduced and practised in controlled lexical exercises is not easily accessible either in free speech or writing. Secondly, to develop lexical sophistication, teachers should be familiar with lexical frequency lists, especially with the list of $1 \mathrm{k}$ words. Only if equipped with lexical frequency lists, would they be able to diagnose the level of lexical sophistication in their learners' language production and take steps to help their learners develop this aspect of language performance so that they become not only communicatively efficient but also advanced and precise language users. Thirdly, the teachers should realize that the more $1 \mathrm{k}$ words learners use, the fewer advanced words they will produce, not to mention the fact that the reliance on $1 \mathrm{k}$ words slows down the rate of growth of more sophisticated words. Thus, expending time and effort on the development of words beyond the first 
level will foster the development of words from further levels. This, however, calls for the implementation of efficient teaching techniques and learning strategies which would lead to greater complexification and automatization of lexical knowledge.

\section{REFERENCES}

Ai, H. / Lu, X. (2010). A web-based system for automatic measurement of lexical complexity. Paper presented at the 27th Annual Symposium of the Computer-Assisted Language Consortium (CALICO-10). Amherst, MA. June 8-12.

Anthony, L. (2014). AntWordProfiler (Version 1.4.1) [computer software]. Tokyo, Japan: Waseda University. https:/ / www.laurenceanthony.net/software [access: 20.10.2020].

Baba, K. (2020). Exploring dynamic developmental trajectories of writing fluency: Who benefited from the writing task? In: G. Fogal / M. Verspoor (eds.), Complex dynamic systems theory and L2 writing development (pp. 3-26). Amsterdam / Philadelphia: John Benjamins. https://doi. org/10.1075/1llt.54.01bab [access: 20.10.2020].

Baba, K. / Nita, R. (2014). Phase transitions in the development of writing fluency from a complex dynamic systems perspective. Language Learning, 64 (1), 1-35. https:/ / www.researchgate.net/ publication/259553956 [access: 20.10.2020].

de Bot, K. (2017). Complexity theory and Dynamic systems theory: Same or different? In: L. Ortega / Z. Han (eds.), Complexity theory and language development. In celebration of Diane Larsen-Freeman (pp. 51-58). Amsterdam / Philadelphia: John Benjamins.

de Bot, K. / Lowie, W. / Verspoor, M. (2007). A dynamic systems theory approach to second language acquisition. Bilingualism: Language and Cognition, 10 (1), 7-21. https:/ / www.researchgate. net/publication/231787985 [access: 20.10.2020].

Browne, Ch. / Culligan, B. (2016). The TOEIC service list (TSL) and Business service lists (BSL). http:/ / www.newgeneralservicelist.org [access: 20.10.2020].

Browne, Ch. / Culligan, B. / Phillips, J. (2013). The new general service list (NGSL) - The most important words for second language learners. http:/ / www.newgeneralservicelist.org/ [access: 20.10.2020].

Bulté, B. / Housen, A. (2012). Defining and operationalizing L2 complexity. In: A. Hounsen / F. Kuiken / I. Vedder (eds.), Dimensions of L2 performance and proficiency: Complexity, accuracy and fluency in SLA (pp. 23-46). Amsterdam / Philadelphia: John Benjamins. https:/ / www. academia.edu/27458664/ [access: 20.10.2020].

Bulté, B. / Housen, A. (2014). Conceptualizing and measuring short-term changes in L2 writing complexity. Journal of Second Language Writing, 26 (4), 42-65. https:/ / www.researchgate.net/ publication/280256988 [access: 20.10.2020].

Caspi, T. (2010). "A dynamic perspective on second language development". Unpublished doctoral dissertation. University of Groningen, the Netherlands.

Cobb, T. (2012). The Compleat lexical tutor for data-driven learning on the Web (v.6.2). Montreal University of Quebec [computer software]. https://www.lextutor.ca/vp/ [access: 20.10.2020].

Coxhead, A. (2000). A new academic word list. TESOL Quarterly, 34, 213-38. https:/ / www.wgtn. ac.nz/_data/assets/pdf_file/0020/1626131/Coxhead-2000.pdf [access: 20.10.2020].

Davis, M. (2012). Corpus of contemporary American English (1990-2012). http:/ / corpus.byu.edu/ coca/ [access: 20.10.2020]. 
van Dijk, M. / Verspoor, M. / Lowie, W. (2011). Variability and DST. In: M. Verspoor / K. de Bot / W. Lowie (eds.), A dynamic approach to second language development (pp. 55-84). Amsterdam / Philadelphia: John Benjamins.

Durán, P. / Malvern, D. / Richards, B. / Chipere, N. (2004). Developmental trends in lexical diversity. Applied Linguistics, 25 (2), 220-242. https:/ / doi.org/10.1093/applin/25.2.220 [access: 20.10.2020].

van Ek, J. / Trim, J. (1998a). Threshold 1990. Council of Europe. Cambridge: CUP. https://www. ealta.eu.org/documents/resources/Threshold-Level_CUP.pdf [access: 20.10.2020].

van Ek, J. / Trim, J. (1998b). Waystage 1990. Cambridge: CUP. https://www.ealta.eu.org/documents/resources/Waystage_CUP.pdf [access: 20.10.2020].

Eldridge, J. (2008). No, there isn't an 'academic vocabulary', but... A reader responds to K. Hyland and P. Tse's "Is there an 'academic vocabulary'”?, TESOL Quarterly, 42 (1), 109-113. https:/ / onlinelibrary.wiley.com. doi/10.1002/j.1545-7249.2008.tb00210.x. [access: 20.10.2020].

Ellis, R. (2007). The study of second language acquisition. Oxford: Oxford University Press.

Gardner, D. (2013). Exploring vocabulary. Language in action. New York: Routledge http://www. routledge.com/books/details/9780415585453/ [access: 20.10.2020].

van Geert, P. / Dijk, M. (2002). Focus on variability: New tools to study intra-individual variability in developmental data. Infant Behaviour and Development, 25, 340-375. https:/ / www.paulvangeert.nl/publications_files/vangeert_variability.pdf [access: 20.10.2020].

van Geert, P. / Verspoor, M. (2015). Dynamic systems and language development. In: B. MacWhinney / W. O'Grady (eds.), The handbook of language emergence (pp. 537-556). New York: Wiley and Sons. https://www.researchgate.net/publication/314003688 [access: 20.10.2020].

Hiver, P. / Al-Hoorie, A. (2020). Research methods for Complexity theory in applied linguistics. Bristol: Multilingual Matters.

Hou, J. / Loerts, H. / Verspoor, M. (2020). Coordination of linguistic subsystems as a sign of automatization? In: G. Fogal / M. Verspoor (eds.), Complex dynamic systems theory and L2 writing development. Amsterdam / Philadelphia: John Benjamins. https:/ / doi.org/10.1075/1llt.54.02hou. [access: 20.10.2020].

Housen, A. / Kuiken, F. / Vedder, I. (2012). Complexity, accuracy and fluency. Definitions, measurement and research. In: A. Hounsen / F. Kuiken / I. Vedder (eds.), Dimensions of L2 performance and proficiency: Complexity, accuracy and fluency in SLA (pp. 1-20). Amsterdam / Philadelphia: John Benjamins.

Hyltenstam, K. (1988). Lexical characteristics of near-native second-language learners of Swedish. Journal of Multilingual and Multicultural Development, 9 (1/2), 67-84. https:/ / www.tandfonline. com/doi/abs/10.1080/01434632.1988.9994320 [access: 20.10.2020].

Knoch, U. / Rouhshad, A. / Storch, N. (2014). Does the writing of undergraduate ESL students develop after one year of study in an English-medium university? Assessing Writing, 21 (1), 1-17. https://www.sciencedirect.com/science/article/abs/pii/S1075293514000026 [access: 20.10.2020].

Larsen-Freeman, D. (2006). The emergence of complexity, fluency and accuracy in the oral and written production of five Chinese learners of English. Applied Linguistics, 27, 590-616. https:/ / www.academia.edu/38727423/ [access: 20.10.2020].

Larsen-Freeman, D. / Cameron, L. (2008). Complex systems and applied linguistics. Oxford: Oxford University Press.

Laufer, B. / Nation, P. (1995). Vocabulary size and use: Lexical richness in L2 written production. Applied Linguistics, 16, 307-322. https://doi.org/10.1093/applin/16.3.307 [access: 20.10.2020]. 
Linnarud, M. (1986). Lexis in composition. A performance analysis of Swedish learners' written English. Lund: CWK Gleerup.

MacWhinney, B. (2000). The CHILDES project: Tools for analyzing talk. Mahwah: Lawrence Erlbaum Associates. https://dighumlab.org/clan/ [access: 20.10.2020].

Meara, P. / Bell, H. (2001). P_Lex: A simple and effective way of describing the lexical characteristic of short L2 text. Prospect. A Journal of Australian TESOL, 16 (3), 5-19. http:/ / www.lognostics. co.uk/vlibrary/meara\&bell2001.pdf [access: 20.10.2020].

Meara, P. / Miralpeix, I. (2016). Tools for researching vocabulary. Bristol: Multilingual Matters.

Nation, P. (2004). A study of the most frequent word families in the British National Corpus. In: P. Bogaards / B. Laufer (eds.), Vocabulary in a second language: Selection, acquisition, and testing (pp. 3-13). Amsterdam / Philadelphia: John Benjamins.

Nation, P. (2012). The BNC/COCA word family lists. http:/ / www.victoria.ac.nz/lals/about/staff/ paul-nation [access: 20.10.2020].

Nation, P. / Heatley, A. (2002). Range: A program for the analysis of vocabulary in texts [computer software]. http://www.vuw.ac.nz/lals/staff/paul-nation/nation.aspx [access: 20.10.2020].

Norris, J. / Ortega, L. (2009). Towards an organic approach to investigating CAF in instructed SLA: The case of complexity. Applied Linguistics, 30 (4), 555-578. https:/ /www.researchgate. net/publication/249237888 [access: 20.10.2020]

Nuance ${ }^{\circledR}$ (2014). Dragon Naturally Speaking Premium. Speech recognition software. https:/ /www. nuance.com/dragon/support/dragon-naturallyspeaking.html [access: 20.10.2020].

Read, J. (2000). Assessing vocabulary. Oxford: Oxford University Press.

Rokoszewska, K. (2019a). Intra-individual variability in the emergence of complexity, accuracy and fluency in speaking English at secondary school - A case study of a good, average and poor language learner. Anglica Wratislaviensia, LVII, 181-204. https:/ / wuwr.pl/awr/article/ view/269 [access: 20.10.2020].

Rokoszewska, K. (2019b). Intra-individual variability in the emergence of syntactic complexity in English L2 speech at secondary school - A case study of a good, average and poor language learner. Konin Language Studies, 7 (4), 445-473. http:/ /www.ksj.pwsz.konin.edu.pl/wp-content/uploads/2020/03/KSJ-74-445-473-Rokoszewska.pdf [access: 20.10.2020].

Rokoszewska, K. (2020a). Fluency and complexity as coupled growers in speaking English at secondary school - a case study of a good, average, and poor language learner. Linguistics Beyond and Within, 6, 160-174. https://czasopisma.kul.pl/LingBaW/article/view/11838 [access: 20.10.2020].

Rokoszewska, K. (2020b). Intra-individual variability in the emergence of lexical complexity in speaking English at secondary school - A case study of a good, average and poor language learner. Theory and Practice in Second Language Acquisition, 6 (1), 107-142. https:/ / www.journals us.edu.pl/index.php/TAPSLA/article/view/7929 [access: 20.10.2020].

Rokoszewska, K. (2021). Accuracy and complexity as connected growers in L2 English speech at secondary school - a case study of a good, average and poor language learner. Neofilolog, 56 (1), 71-90.

Spoelman, M. / Verspoor, M. (2010). Dynamic patterns in the development of accuracy and complexity: A longitudinal case study on the acquisition of Finnish. Applied Linguistics, 31 (4), 532-553. https://www.researchgate.net/publication/241686051 [access: 20.10.2020].

Storch, N. / Tapper, J. (2009). The impact of an EAP course on postgraduate writing. Journal of English for Academic Purposes, 8 (3), 207-223. https:/ / www.sciencedirect.com/science/article/ abs/pii/S1475158509000277 [access: 20.10.2020].

Text Inspector. (2018). Online lexis analysis tool. textinspector.com [access: 20.10.2020]. 
Verspoor, M. / de Bot, K. / Lowie, W. (2011). A dynamic approach to second language development. Amsterdam / Philadelphia: John Benjamins.

Verspoor, M. / Lowie, W. / van Geert, P. / van Dijk, M. / Schmid, M.S. (2011). How to sections. In: M. Verspoor / K. de Bot / W. Lowie. (eds.), A dynamic approach to second language development (pp. 129-199). Amsterdam / Philadelphia: John Benjamins.

West, M. (1953). A general service list of English words. Green: Longman.

Wolfe-Quintero, K. / Ingaki, S. / Kim, H.Y. (1998). Second language development in writing: Measures of fluency, accuracy, and complexity (Report No. 17). Honolulu: University of Hawaii, Second Language Curriculum Centre.

Xue, G. / Nation, P. (1984). A university word list. Language Learning and Communication, 3 (2), 215-29. Zheng, Y. (2016). The complex, dynamic development of L2 lexical use: A longitudinal study on Chinese learners of English. System, 56, 40-53. https:/ / www.sciencedirect.com/science/article/ abs/pii/S0346251X15001852 [access: 20.10.2020].

Received: 20.10.2020; revised: 30.03 .2021

KATARZYNA ROKOSZEWSKA

Uniwersytet Humanistyczno-Przyrodniczy im. Jana Długosza w Częstochowie k.rokoszewska@ujd.edu.pl

ORCID: 0000-0003-4479-0385 
